\title{
一般 44
}

\section{超音波検査による痛風発作時と尿酸降下薬投与後の 母趾 MTP関節における尿酸塩沈着の比較検討}

森戸 俊典 ${ }^{1)}$ 清水 徹 ${ }^{2}$

背 景

関節に尿酸ナトリウム塩（MSU）結晶が蓄積 していても必ず痛風発作を起こすとは限らず，発 作を起こす関節と起こさない関節のMSU結晶の 蓄積に違いがあるのかは不明な点が多い。また, 尿酸降下薬投与により血清尿酸值をコントロール すると関節に蓄積した結晶がどのように変化する のか未だ十分に解明されていない.

\section{目的}

母趾 MTP 関節の超音波検査にて, 痛風発作中 と尿酸值がコントロールされ発作が鎮静化してい る時のMSU結晶蓄積の所見を観察し比較・検討 した。

\section{対象と方法}

尿酸降下薬の投与歴がなく母趾 MTP 関節片側 性の発作中で, 反対側は発作の既往がない痛風症 例の両側母趾MTP関節を「痛風発作群」，母趾 MTP 関節に発作の既往があり， 1 年以上尿酸降下 薬の投与を継続しかつ血清尿酸值が 1 年以上 $7.0 \mathrm{mg} / \mathrm{dl}$ 未満で発作が鎮静化している痛風症例の 両側母趾MTP関節を「尿酸コントロール群」と 定義した。痛風発作群は, 2012年 5月～2014年 10 月に当院を受診した男性痛風症例 35 例 70 関節 (年齢中央值 57 歳) で，そのうち 23 例が初回発作 であった. また, 発作時血清尿酸值は中央值 $7.5 \mathrm{mg} /$ d l であった，尿酸コントロール群は，男性痛風症 例 65 例 130 関節 (発作歴あり 78 関節, なし 52 関節)
で年齢中央值 54 歳, 尿酸降下薬の投与期間は中 央值 6 年 10 力月であり, 2013 年 7 月〜 2014 年 9 月に超音波検査を施行したが施行時の血清尿酸值 は中央值 $5.5 \mathrm{mg} / \mathrm{dl}$ であった。

超音波検査には, 日立アロカメディカル社の Prosound $\alpha 6$ またはNoblusを使用し，Bモード法 にて関節内の MSU結晶蓄積の有無をdouble contour sign（以下 DCS）または結節像の 2 点に絞 り観察した.

\section{結果}

1 ) 痛風発作群

DCS は発作関節 $71.4 \%$ （25/35），発作のない 関節 45.7\%（16/35），結節像は発作関節 94.3\% (33/35)， 発作のない関節 60\%（21/35） に認め られ，どちらも発作関節の方が頻度は有意に高 かった $(\mathrm{p}<0.05, \mathrm{p}<0.001)$ 。また, 発作関節の 全例にDCS と結節像の一方または両方を認め, DCS と結節像両方が存在する関節が $66 \%$ （23/35）と多数を占めた.

2 ）尿酸コントロール群

DCS の頻度は発作歴のある関節 $50.0 \%$ (39/78)，発作歴のない関節 32.7\%（17/52）で 両者間に有意差を認めず，結節像の頻度は其々 69.2\% (54/78)，23.1\%（12/52）で有意差を認 めた $(\mathrm{p}<0.0001)$. また, 発作歴のある関節, ない関節ともにDCS と結節像両方存在しない 関節が増加した $(23.1 \%, 57.7 \%)$.

3 ) 痛風発作群と尿酸コントロール群の比較
1）森戸整形外科医院

2）みどりヶ丘病院リウマチ科
Toshinori Morito

Toru Shimizu 
発作歴のある関節において, 尿酸コントロール 群ではDCS, 結節像の頻度がともに発作群より 有意に低かった $(\mathrm{p}<0.05, \mathrm{p}<0.005)$ 。しかし，発 作歴のない関節においてDCSの頻度は有意差を 認めず，結節像の頻度は有意差を認めた $(\mathrm{p}<0.001)$.

\section{考察}

発作中の関節ではMSU結晶蓄積が必ず証明さ れると考えられ，DCS と結節像両者が存在する
頻度が高い。尿酸值をコントロールすると, $\mathrm{MSU}$ 結晶は減少または消失する。発作歴のある 関節のDCS は消失しやすく，発作歴のない関節 のDCSは消失しにくい傾向が観察された。

\section{結 論}

MSU結晶の蓄積量が多い方が発作を起こしや すく, DCSの方が結節像よりも痛風発作の起こ りやすさに関連する所見と思われた。 